\title{
Costumes on set: Congos's symbolic language
}

Figurinos no set: a linguagem simbólica do Congos

\section{Paula Piva Linke}

Universidade de São Paulo

Centro Universitário Metropolitano de Maringá

paulapivalinke@gmail.com

M

전

PROJËTICA

COMO CITAR ESTE ARTIGO:

LINKE, P. P. Costumes on set: Congos's symbolic language. Projética, Londrina, v. 11, n. 1, p. 104-137, 2020. Supl.

DOI: 10.5433/2236-2207.2020v11n1suplp104

Submissão: 04-02-2019

Aceite: 18-09-2019
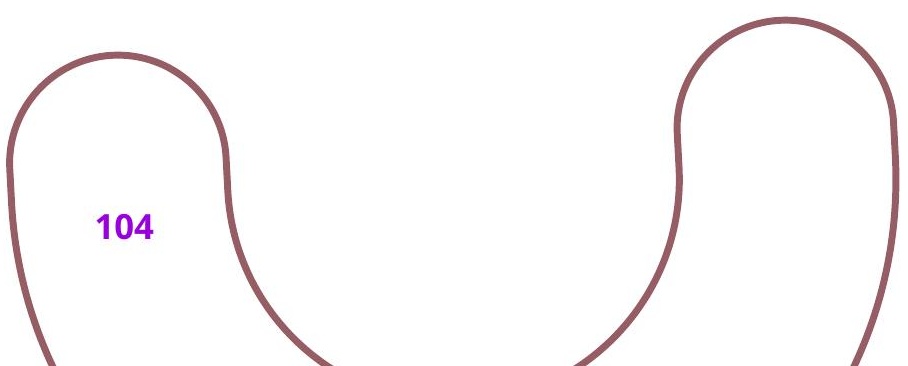
ABSTRACT: Taking place in Lapa, state of Paraná, Brazil, the Congada includes the festivities in honor of Saint Benedict and is a Festival which combines a cultural miscellanea with African, Portuguese and Brazilian characteristics. This paper aims to present how clothing behaves as a symbolic and meaningful component of the Lapa's Congada. A documentary produced by LUX AGD in 2004 along with the folkloric book Congadas Paranaenses by José Loureiro Fernandes are used as sources for this research.

Key words: Cultural history. Congada. Clothing. Fashion.

RESUMO: Ocorrendo na Lapa, Estado do Paraná, Brasil, a Congada compõe as festas em honra de São Bento e é uma celebração que apresenta uma miscelânea cultural com características africanas, portuguesas e brasileiras. Este texto tem como objetivo apresentar as funções do vestuário como um componente simbólico e significativo de Congada da Lapa. Um documentário produzido pela LUX AGD em 2004 junto com o livro folclórico Congadas Paranaenses escrito por José Loureiro Fernandes são usados como fontes para esta pesquisa.

Palavras-chave: História cultural. Congada. Indumentária. Moda.

\section{INTRODUCTION}

The Congada is a celebration which takes place in Lapa, a town from the state of Paraná, in the South of Brazil. This celebration is part of a bigger one, the Feast of Saint Benedict. It displays a cultural miscellany from a few specific origins. A Portuguese influence can be seen on costumes and staging organization. Each year, pointing to African traces, the event celebrates a saint who has to be black with 
Projética, Londrina, v. 11, n. 1, supl. Design de Moda, p. 104-137, maio 2020

slave parents. Also, the religious aspects of Congada give the celebration specific social and cultural characteristics referring to the belonging of the celebration to the city itself and to those who created the celebration.

This text aims to explicit how clothing functions as a symbolic and meaningful component of the Lapa's Congada. A documentary produced by LUX AGD in 2004 along with the folkloric book Congadas Paranaenses by José Loureiro Fernandes are used as sources for this research. As the costumes have their language, they must be looked upon taking into account the cultural codes of the historical moment in which they emerge as well as their relationship with tradition. The analyses move towards the King of Congo costume and other objects that are part of the staging.

In the first section of the text, the Congada festival and its general aspects are presented with a reflection on culture and memory from a dynamic point of view. The Lapa's Congada with its particularities and how tradition and culture mingle are discussed in the second section. The paper continues with a theoretical discussion on the importance of costumes and their role in building meanings. Lastly, a particular set of costumes, the ones from the King of Congo, are analyzed along with some objects present in the celebration.

The staging has a specific language translated into the practice and representation of beliefs and myths that are part of the African descent memory. Therefore, representation is understood as an ideological and mental construction shared by members of a group or society where multiple cultural elements articulate themselves creating specific languages (CHARTIER, 1988; GEERTZ, 1998). 


\section{Costumes on set: Congos's symbolic language}

LINKE, P. P.

\section{CONGADA}

The Congada is a popular Brazilian Festival with African origin that is celebrated in the North, Certer and South of the country. Whereas the name Congada is used in this text, the festival is also known as Congados and Congos. The characterizing features of the Festival are the coronation of the Congo King; the procession and the embassies; the recalling of warrior dances and fights and of the Queen Ginga (CASCUDO, 1984). The first Congada registered in Brazil occurred in Recife, 1674 (CEZAR, 2008, p. 2). Its origins are remote and distributed through America:

The election of black kings and its festive commemoration was more spread out in Portuguese America, with scientific proof of it existence dating back to the beginning of the twenty-seventh century. It gained strength in the twenty-eighth century, changed its appearance in the twenty-ninth century and happens until today in several Brazilian locations (SOUZA, 2006, p. 79).

The festival has never happened in African territory in the same way as they are seen and documented in Brazil, it is rather a work of Brazilian slaves. (CASCUDO, 1984). Nevertheless, it brings along distinctive features from the African slavery and the life, yearnings, devotion and memories of the enslaved ones. The African scope characterizes and differentiates the Congada from other festive manifestations.

The coronation of Congo Kings, especially as registered in the XIX century, clearly shows the African influence as each year celebrated a founding myth of the black catholic community, with the African ancestor being invocated in a Christianized version. However, the African influence is not the only one present. The celebration is actually a product of the meeting between African and Iberian cultures, with the festival incorporating elements of both in a new cultural formation in which the symbols gain new meanings (SOUZA, 2006). 
Projética, Londrina, v. 11, n. 1, supl. Design de Moda, p. 104-137, maio 2020

In this work, culture is considered a dynamic process that manifests itself in different forms, at different historical moments and contexts, with changes of meaning and interpretation of the symbols that are part of it as individuals of different generations live and interpret the celebration differently (ARIZPE, 2009; GEERTZ, 1998).

It is, thus, due to the variety of ethnicities and cultural practices that formed the enslaved population of Brazil that the Congada incorporated distinct cultural elements. Its origination process comes from the many commemorations carried out in the brotherhoods of black men which became the characterizing features mentioned before: the crowning of black kings festival, in which the black community recognized one of its own as sovereign; the embassies, in which parades and choreographic dances were present; the war dances and celebrations in which the war and the fights between African kingdoms were presented (CASCUDO, 1984). This variety of practices modified itself with time and assumed new configurations resulting in diverse cultural manifestations, the Congada being one of them.

It is through this incorporation of symbols and different cultures that the Congada builds itself as a celebration in which the African past is remembered and an identity to is created within the black community of the New World. The coronation of the Kongo King is a:

Space of identities construction and power expression which organized the internal relationships in the group as well as the relationships of the group with the society as a whole in respect to hierarchies, power exercise and solidarity. Generally originated within the brotherhoods, the communities which carried out the festival assumed European forms of organization in order to show their own cultural values permeated by African elements (SOUZA, 2006, p. 18-19). 


\section{Costumes on set: Congos's symbolic language}

LINKE, P. P.

The Congada also possesses a religious character in which a combination of African culture and Catholicism is present, translating the religious syncretism in which the slaves had to live in. Among the variety of distinct cultural elements, it is possible to see the homage to catholic Saints mixed with African music and dance. Saint Benedict, Our Lady of the Rosary and Saint Iphigenia are among the saints who captivated the faith of the slaves and are celebrated in the Festival.

A relevant fact to be considered is that along with the baggage from the national slaves, the Congada has also been influenced by the Portuguese culture while still in the African continent. As the kingdom of Congo contacted the Portuguese, it assumed some of their cultural elements such as clothing, nobility titles and names. Another impactful factor was the incorporation of Catholicism, which suffered several modifications as not all African religious practices had been forgotten, but rather adapted the new religion. In such a way, many of the captives who come to Brazil already knew some practices from the Portuguese culture or had had contact with them when they were in the ports to embark for the other continent (HEYWOOD, 2010).

When these black people arrived in Brazil, with their familiar and social bonds destroyed and living under the new rules of the slave system, they looked for other ways to restore bonds, since it was impossible to reestablish their original culture. They had found in the Brotherhoods of Black Men a form to establish new bonds and to normally conserve part of its culture by means of the parties of crown of black kings, who occurred to homage a saint, of color, Ours Lady of the Rosary, Is Benedict, Iphigenia Saint, amongst others (REIS, 1991).

For the Africans the kingdom of the Congo was symbol of being able and sovereignty and its King strong figure in myths of origin of the same became, as well as the figure of Queen Njinga, leader of the region of Matamba. These two figures represent the memory of mythical and powerful Africa, remaining in the souvenir 
Projética, Londrina, v. 11, n. 1, supl. Design de Moda, p. 104-137, maio 2020

of the captives and it's you descended, occupying paper of prestige in the crowns of black kings who occurred in the brotherhoods of black men (SOUZA, 2006).

Initially these parties of crown of black kings counted on the support of the Church, that saw the brotherhoods and these celebrations as form of catechize the captives, but on the time, had passed to be seen as threat, therefore with the great number of slaves it would be relatively easy to initiate a rebellion. At different moments the crowns of black kings accepted and had been restrained by the Church and the State, but although the innumerable attempts of the authorities, it remained, if modifying through centuries XVIII, XIX and XX and remaining until the present (REIS, 2002).

More than what a simple celebration, the Congada is on to a constructed identity inside of the brotherhoods and that was remained although the prohibitions and of the time. Present solidarity in the relations between slaves and the brotherhoods together with the desire to relive the past and the African culture originated the crown of black kings, celebration that importance acquired before the community of afro-descendants and that it remains as element that composes the past of the enslaved one, the gift of its descendants.

Also, memory expresses itself in several ways, not only in the speeches of people, but also in written form and in the knowledge, beliefs and many objects which are part of and have a specific meaning for the group or the individual (ALMEIDA; KOURY, 2014; BOSI, 1994). Therefore, keeping a tradition is more than registering verses or music; it means cultivating the elements of the material and immaterial culture so that it conserves its identity and has meaning to the group. Conserving the objects of the staging, as well as knowledge about them, is a way to keep the memory, which is transmitted to the community and to the new generations so that other people commit to continuing the tradition and to conserving the values that are part of it (ARIZPE, 2009). 


\section{Costumes on set: Congos's symbolic language}

LINKE, P. P.

In addition, it is exactly because of the identity and the concern in transmitting this legacy that the Lapa's Congada is considered a cultural patrimony of the city, something to be conserved and to be recollected. In such a way, the preservation goes beyond what is material and reaches the beliefs and forms of expression that are part of this culture and which give form and meaning to the material elements that are part of it (FONSECA, 2009).

The immaterial patrimony is transmitted from generation to generation and constantly recreated by the communities and groups due to its environment, its interaction with nature and its history, generating a feeling of identity and continuity (ARIZPE, 2009; FONSECA, 2003).

The subjects are responsible for valuing, creating and recreating their traditions so that they can be transmitted to the next generations. This fact implies in considering that as much as culture is dynamic, so is tradition. Even though there is a process of tradition resignification, it does not mean that it loses aspects of its traditional character since each individual sees it differently and incorporates different values and beliefs to it. In the same way that individuals change, so does tradition, as it is a cultural manifestation created by several subjects (ARIZPE, 2009).

\section{THE LAPA'S CONGADA}

The cultural diversity of the Congada, which was mentioned before, also derives from where it occurs, as the location plays an important role in the contextualization of the tradition, once each place is connected to specific climatic, geographic, economic, political and cultural characteristics that are part of the elements that build identities and traditions. It is, therefore, relevant to explore the fact that the Congada practiced in the city of Lapa has unique characteristics, which differentiate it from other festivals that still occur today in other localities of Brazil. 
Projética, Londrina, v. 11, n. 1, supl. Design de Moda, p. 104-137, maio 2020

The Congada arrived in Lapa around the year 1820. It was brought by the movement of the troopers who had left Viamão (in the state of Rio Grande do Sul) in route to Sorocaba (in the state of São Paulo), traversing the Campos Gerais in Paraná with the city of Lapa being one of the main stopping points (FERNANDES, 1977). The small town grew due to the intense activity of the troopers who camped there during the night. With time, other activities developed and the town grew. The families who inhabited the village built it themselves, however the action of anonymous social actor working as slaves and aggregates was also present as they performed all the necessary work to maintain the farms in the region (SILVA, 2007). Due to its location and to how it developed, the city kept some popular manifestations, such as the Congada, alive.

The Congada consisted of a celebration of a conflict between two kingdoms. Dance, music and choreography represented the disputes between the Congo's King and the Angolan Queen. The Congo's King (the Land's Saint) was assisted by a court of Nobles while the Embassy of Ginga (Queen of Angola) was assisted by the Army and by the Ambassador. The combat culminated in the defeat of the visiting Embassy and the consequent pardon of the Congo's King to the Ambassador, thus the kings of Angola and the Congo were united under the protection of the Black Saint (CASCUDO, 1984).

According to Fernandes (1977), the Lapa's Congada is composed of 12 scenes: initial parade; line of the throne; dance of the nobles; arrival of the Angolan's queen embassy; entrance of the ambassador; declaration of war; second war - fight between the Congo's nobles and the Angolan people - arrest of the ambassador; arrival of the prisoners at the court of the Congo; royal pardon; arrival of the embassy; farewell of the Angolan ambassador; final parade of fraternization.

The Lapa's Congada originated, as in many other places, as homage to Saint Benedict, a saint of humble origin, whose life history has captivated the faith 


\section{Costumes on set: Congos's symbolic language}

LINKE, P. P.

of the Brazilian slaves. The Brotherhoods of Black Men and their festivals were present in many Brazilian states, and in the case of Lapa, both the Congada and the Brotherhood of Saint Benedict are alive until this day.

The Lapa's Congada remembers the beautiful life example of Saint Benedict, making him the protagonist of the play. Saint Benedict was born in Italy and conquered first the heart of the simple populations of Sicily because of the miracles and favors he distributed when still alive. The devotion to this saint was brought to Brazil by the Franciscan order even before his beatification, aiming to increment the devotional Catholicism among the poor and the enslaved people, guaranteeing a protector to the deported blacks (DELL' AIRA 1999 apud SILVA, 2008).

Because of the popular beliefs in the goodness of Saint Benedict and the attribution of miracles to his name, the life history of the saint conquered the faith of the captives who started to carry out parties in its homage, extolling their beliefs and their ancestors past. When people celebrate, they feel as part of the history approached, not only as actors or members of the group, but also as subjects who keep the tradition in their daily life. The transmission, in turn, must incorporate new ways of seeing and interpreting the staging, what confers new cultural meanings to it.

Although the official patron of the city is Saint Anthony, Saint Benedict is considered a co-patron and is honored. The faith in the saint was initially spread among the slaves who built a small chapel in the highest point of the city, where the pillory was located. Later on, this chapel gave place to the Sanctuary of Saint Benedict (SILVA, 2007). In order to praise their saint, the slaves would make a celebration on the December 26th. The Congada was performed in this celebration with the help of the slaves' owners who viewed it as a way to display their wealth and power (FERNANDES, 1977). 
Projética, Londrina, v. 11, n. 1, supl. Design de Moda, p. 104-137, maio 2020

Once slavery met its end, the congos' group went through some difficulties such as the rupture with the members of the Saint Benedict's Brotherhood and a lack of interest from the community in assisting in the maintenance of the celebration. This context was responsible for a period of seventeen years without the celebration being carried out (NASCIMENTO, 2009).

It is important to highlight that, despite the difficulties, the members of the Lapa's black community organized themselves and, although the Congada had not been carried out for 17 years, it began to be staged again. That was due to the work of the congos and of the last king descendant. On January 16th, 1994, the Fundação Cultural Afro-Lapeana (Cultural Foundation of Afro descendants from Lapa, in Portuguese, provisory name) was created.

However, even after this attempt, difficulties continued and in 2004 the Lapa's Congada was revitalized by a project in partnership with Lux Agd and Petrobrás'. The congos received new instruments and music lessons and rescued the choreographs, clothes and costumes of the participants (CONGADA..., 2005).

[1] LUX AGD - A LUX - AGENCIA DE DESENVOLVIMENTO é um(a) associação privada de Curitiba - PR fundada em 03/07/2002. Sua atividade principal é atividades de associações de defesa de direitos sociais Petrobras - Petróleo Brasileiro S.A. é uma empresa de capital aberto, cujo acionista majoritário é o Governo do Brasil. É, portanto, uma empresa estatal de economia mista. 
This process of revitalization, however, has been interfering in the codes that compose the costumes worn by the participants. Despite being based on old photographs and descriptions made by the participants themselves, the costume designers ended up interfering in the costumes, sometimes intentionally and sometimes not. These interventions do not have to be seen as positive or negative, but as elements that benefit to the dressing submitted to the censorship of the group and which mark another stage in the process of permanence of the Congada in the city of Lapa.

\section{THE IMPORTANCE OF CLOTHES AS SIGNIFICANT OBJECTS}

The language of clothes created by their use along with props, adornments and accessories varies a lot and takes on different functions depending on how it is used by the individual. The act of communicating through fashion requires a detailed interpretation of its signs and symbols, since small changes cause great transformations in meaning and use. Not only are the clothes themselves an important element, but also the knowledge on how to use them, which complements their meaning.

“The different positions in the social space correspond to life styles, the differential deviation systems which are the symbolic translation of objective differences inscribed on the conditions of existence" (ORTIZ apud WAJNMAM; ALMEIDA, 2002, p. 72). The way in which an individual expresses his or her tastes for dressing and the way he or she interacts symbolically with clothing depends on the environment and on how the group where he or she lives makes use of clothing. That is why traditional clothes express part of the experiences of a group or individual.

The characteristic representation of the costumes is part of the many symbologies in the Congada. Such symbologies are present in how each character 
Projética, Londrina, v. 11, n. 1, supl. Design de Moda, p. 104-137, maio 2020

wears the clothing and how it fulfills its role in the celebration, that is, how it presents the power hierarchy and how it uses visual language to express the identity of the play (NERY, 2003).

Clothes, as artifacts, create behaviors due to their capability to impose social identities and to allow people the affirmation of latent social identities. [...] On the other hand, clothes can be seen as a vast reservoir of meanings susceptible to manipulation and to reconstruction in a way which strengthens the personal sense of influence (CRANE, 2006, p. 22).

Therefore, the clothes are more than a second skin, more than an object to cover and heat the body. Clothes are a building element of the subject identity and his or her status. "The fashion and the clothes are meaningful practices; they are ways of generating meanings. They produce and reproduce social groups as well as their relative power positions" (BARNARD, 2003, p. 64). Although clothes serve as a distinction and have specific meanings, it is important to point out that the codes vary with time. "Fashion contributes to the redefinition of social identities by constantly attributing new meanings to artifacts" (CRANE, 2006, p. 43).

[...] but it is relevant to point out here that fashion and dressing are not only used to indicate or to make reference to social and cultural positions, but also to build and to mark, first of all, that specific social and cultural reality. What is being said here is that people build themselves as social and cultural beings through fashion and dressing (BARNARD, 2003, p. 64).

By using clothes in their constitution as social and cultural beings, the individual uses the language of clothing to communicate his or her identity, position, sex and other elements. "Fashion, clothing and dressing are communication forms" (BARNARD, 2003, p. 57). Thus, it can be said "the clothes - this product desired by many - would be a certain symbolic universe transformed into substance" (SAHLINS 
It is relevant to point out here that fashion and dressing are not only used to indicate or to make reference to social and cultural positions, but also to build and to mark, first of all, that specific social and cultural reality. What is being said here is that people build themselves as social and cultural beings through fashion and dressing (BARNARD, 2003, p. 64 
Projética, Londrina, v. 11, n. 1, supl. Design de Moda, p. 104-137, maio 2020

apud CIDREIRA, 2005, p. 105-106). This symbolic universe of clothes is created and recreated under current norms and individuals necessities.

Thus, the corporal appearance is not only seen as a by-product of the social life, the agreed effect of diverse structural and cultural determinisms, but also as a source and a fundamental bet on the dynamics of socialization. It can be considered as an imaginary and mythical instance as it discloses the relationship between the individual and the world, the individual and the others and between the individual and the society (CIDREIRA, 2005, p. 111).

The clothing worn in the Congada takes on a specific role in the celebration which is formed by a series of elements that express certain traditions. The participant's dressing is one of those elements. The clothes worn by the congos assist in the celebration process. Together with music, dance and text, clothing creates a very different environment and reality. They transport the public to the reality staged. Therefore, the clothes worn in the Congada represent a tradition and have a specific function.

It is important to point out that, from the moment the congos appropriate these elements of clothing, the dressing takes on another function, other meanings and objectives. "Man dressed himself to exert his meaningful activity. Beyond reasons of decency, ornamentation and protection, wearing a piece of clothing is essentially an act of signification" (BALDINI, 2005, p. 95). As it has already been mentioned, from 2004 on, the congos's dressing was completely remade through a project of revitalization for the Lapa's Congada. The project reinvigorated the clothes based on old photos and descriptions made by the congos themselves. A team of costume makers participated and took over the responsible for this part of the work. 
The costumes are an element that complements the celebration and posses their own language. They differentiate the characters and use symbols that express a culture. "With respect to the cultural standards, that is, the systems or complexes of symbols, the generic trace of primordial importance for us here is that they represent extrinsic sources of information" (GEERTZ, 1998, p. 106). Therefore, as previously mentioned, the costumes assist in the building of the characters, as well as in the contextualization of the celebration (COSTA, 2002).

Therefore, the clothes must be carefully analyzed as a source of information in order to understand how they express values that differentiate the two groups and the characters that are part of the same group, as is done in the following section. The symbolic meanings attributed to the clothes of the participants are presented taking into consideration all the structure of the celebration, its origins, context and different cultures inside of it, as well as the papers and functions played by each character. The reading of these varied elements makes it possible to understand, for example, the context where the colors are used and what they represent.

\section{PROCEDURES AND METHODS}

To carry out this research, various sources were used, such as newspaper and magazine articles, the Congadas Paranaenses Folklore Notebook, the magazine produced by the Diocesan Shrine of St. Benedict, the commitment of the Brotherhood of St. Benedict, the letter of sponsorship request for the congos group and the DVD with the documentary about the revival of Congada da Lapa.

These sources followed the methodological orientation based on discourse analysis: “Discourses are not, as we said, just messages to be decoded. They are sense effects that are produced under certain conditions and are somehow present in the way it is said" (ORLANDI, 2003, p. 30). 
Projética, Londrina, v. 11, n. 1, supl. Design de Moda, p. 104-137, maio 2020

Since discourse is not just a message to be deciphered, discourse analysis is understood as a method that studies how meaning is produced in the text, interprets the information collected to better understand the facts. Orlandi (2001) describes discourse analysis as a technique that seeks to understand how the text works and not only what it has to say, therefore, considers interpretation as an object of reflection.

Just as the text articulates itself to produce meaning, so does the material culture of the Congada, more specifically the attire of the Congos, symbols of power, wealth and strength. In this sense, the symbol is understood as elements that: "They work to synthesize the ethos of a people - the tone, character and quality of their life, their style and moral and aesthetic dispositions - and their worldview - the picture that makes up what things are in their simple presentness, their broader ideas about order" (GEERTZ, 1998, p. 103-104).

The symbol, "is used for any object, act, event, quality, or relationship that serves as a link to a conception - the conception is the 'meaning' of the symbol" (LANGER apud GEERTZ, 1998, p. 105). The symbols and meanings present in the costumes and the way they are used refer to a worldview of those who stage the Congada.

The staging has a specific language as practice and representation of beliefs and myths that are part of the memory of Afro-descendants. Therefore, representation is understood as an ideological and mental construction shared by the members of a group or society, where several cultural elements are articulated creating specific languages (GEERTZ, 1998).

Once the representations have a specific language, it is necessary to analyze them taking into consideration the entire context in which they are inserted (GEERTZ, 1998). In this particular case, the analysis of the Congada takes into 


\section{Costumes on set: Congos's symbolic language}

LINKE, P. P.

consideration several elements, but the focus is on the costumes that the Congos use in the staging, so a documentary is used as support for analysis, but, more specifically, the photographs that record details of the Congo's clothing.

The photographs are used as documents that allow accessing the representations of the congada, more specifically the attire of the congos. In this case, photography as a source is understood as:

A clipping of our space environment; which is not limited to the visual field we see, but which encloses an experience that transcends the immediate, to place itself in the field of imagination. This can be seen when we perceive objects in relation to others that are distributed in the image and arrange them in different perspectives of proximity, distance, and depth (ZANIRATO, 2003, p. 212).

Beyond this perception of experience, photography allows the viewer to interpret it.

"When we look at an image, we not only perceive its visual structure, we also interpret it. The image offered for reading is a form of text, whose structure is articulated with basic elements such as contrast, color, the volume of the figures and the space that surrounds them" (ZANIRATO, 2003, p. 213).

According to this conception, for the treatment with photography I take as reference Jacques Le Goff (1994). According to this author, photography must be considered simultaneously as image / document and as image / monument. In the first case, photography is considered as an index, as a mark of a past materiality, in which objects, people, places inform us about certain aspects of that past - living conditions, fashion, urban or rural infrastructure, working conditions. etc. In the second case, photography is a symbol, which, in the past, society has established as the only image to be perpetuated for the future. 
Projética, Londrina, v. 11, n. 1, supl. Design de Moda, p. 104-137, maio 2020

Similarly, Ana Maria Mauad (1996) warns that the comprehension of the photographic image, by the reader / recipient, occurs on two levels: the internal level to the surface of the visual text, originated from the spatial structures that constitute such text, nonverbal in character; and externo level external to the surface of the visual text, originated from approximations and inferences with other texts of the same time, including verbal ones. At this level, one can discover familiar themes and infer implicit information.

This is not a detailed analysis of the photographic image. What I did here was a study of the representations of the clothes present in the photographs. Colors, shapes, accessories and adornments were analyzed from the photographic support, since the party did not occur in 2010, making it difficult to access the costumes, which, to be properly studied must be in the body of the Congo, since on a hanger or on a mannequin the costume looks different.

\section{COSTUMES ON SCENE}

For the analysis of the Congos clothes, two documents are used as source. A book called Caderno de Folclore, by Jose Loureiro Fernandes, which was published in 1977, is the first one. The book was published in booklet format and provides details of the staging such as choreographies, clothing and poetry. A revitalization documentary made in 2004 and released in 2005 is the second document. This documentary was sponsored by Petrobras and carried out by LUX - a development agency. It displays the whole process of revitalization and the 2004 staging of the Congada. The documentary presents details of the new clothing, instruments, music and dances.

The costumes of the Congo court, the arms and some symbols, which are part of the gestural protocol of the scenes, were analyzed. 


\section{Costumes on set: Congos's symbolic language}

LINKE, P. P.

"The king and his court doubtless mock the Portuguese monarchy. In the Lapa's Congada, the acute influence of the noble Portuguese customs is present, probably due to the knowledge of the court old habits, which reflected upon the ancient Portuguese nobleman" (FERNANDES, 1977, p. 5).

Since the celebration refers to the Portuguese court, it is common that many of their elements are present: the way of organizing the celebration, beyond the outfits and garments. It is also worth highlighting that the slaves who created this celebration came from the region of Kongo and brought along some elements of the Portuguese culture, already incorporate in Africa, such as the taste for European dressing and noble titles (COSTA, 2002), which is present in the celebration. "Regarding the dressings, it shall be mentioned that they were generically named uniforms, with the noblemen's dressing being very distinct from embassy's one" (FERNANDES, 1977, p. 6). In this case, as well as in the court, there is a difference in the dressings due to social classes, and the same happens in the Congada. The dressing of the King, the Noblemen, the Ambassador and the little congos are different.

The King's dressing deserved special care: the cardboard crown, always wrapped in golden paper, brought secondary garments that highlighted the fake values. The cloak had a particular meaning which is not seen nowadays: the king wore two cloaks, a blue and a red one, both decorated with a wheeled gallon (FERNANDES, 1977, p. 9).

The refinement of the royal costumes described by Fernandes can be observed in pictures 1 . The picture represents the royal family and the costumes in the celebration of 2004. In the left picture, the royal family and the throne can be seen. The white and red costumes with golden details stand out from the rest due to their exuberance and details that decorate the thrones of the King and the Queen. On the background, the presence of the hamlets can be noted, as in the year 
Projética, Londrina, v. 11, n. 1, supl. Design de Moda, p. 104-137, maio 2020

of 2004, the celebration was performed in the street, and the houses that make up its surroundings are part of the photographical compositions.

Picture 1 - The Court of Congo
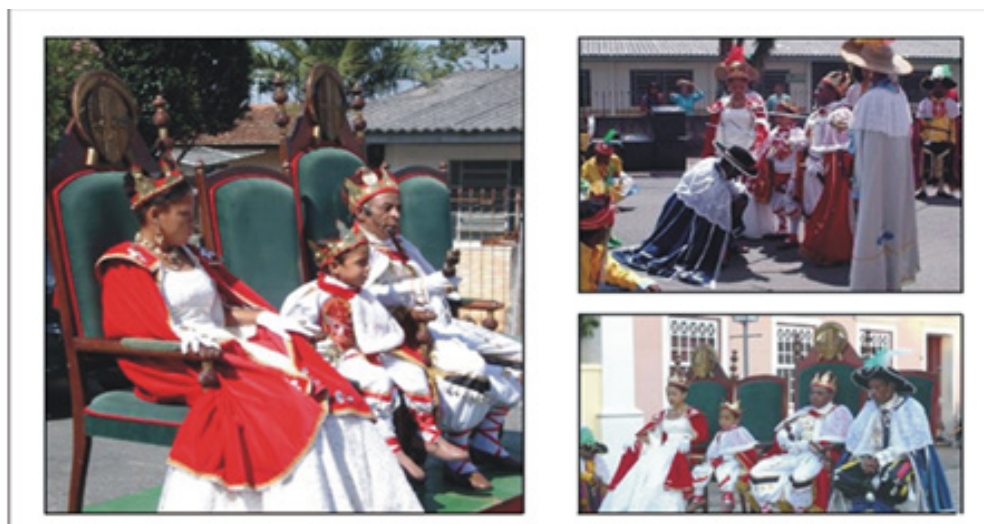

Fonte: Nascimento (2009, p. 255).

On the top right picture, the scene of the ambassador's redemption can be seen, highlighting the congos' royal family, the prince and the Ambassador, who is kneeling, followed by the army of little congos, also kneeling. The nobility is also present, right behind the royal family on the right corner. Os the background, the street hamlets can be seen, as well as the people who accompany the celebration. On the bottom right picture, the royal family and the Ambassador on the platform of the throne can be seen. On the left, one of the noblemen, and on the back, the hamlets which are part of the historical center of Lapa.

This picture is related to three scenes of the Congada. The picture on the left represents the Queen, the little Prince and the Kongo King. The second scene is the Speech of the Throne. On the right picture, top area, there is the redemption of the Ambassador, scene 7, Second war - the fight between the congos's noblemen 


\section{Costumes on set: Congos's symbolic language}

LINKE, P. P.

and the people from Angola - the prison of the Ambassador. On the bottom right picture, there is the representation of scene 10, the Surrender of the Embassy.

These scenes were analyzed through the comparison between the Caderno de Congadas from Paraná by José Loureiro Fernandes (1977) and a documentary produced by LUX (CONGADA..., 2005) after the revitalization process. Scenes 2, 7 and 10 , as shown on picture 1 , are discussed here.

Scene 2 - Throne Line: the dramatic part of the folguedo begins with the first throne line, in which the King provokes the nobility to celebrate, with the entire Christian world, the party of Saint Benedict, and to subdue homage to the Congo King's vassals - Zumbi-Ganiame. The wish of the King is fulfilled, with zealous singing and dancing, noblemen party in honor of the glorious saint together and isolated (FERNANDES, 1977, p. 10).

This scene remains almost the same: the king calls his subjects to honor Saint Benedict. The Noblemen, the Secretary, the Prince, the Standard-bearer, they all sing and dance to praise the Saint. Only a few changes are noticeable in the text, some words replaced, but the whole set and the structure of the lines are the same. The whole text is spoken in a poetical way and in the rhythm of the song that plays along with it. The presence of Saint Benedict's name in the verses is outstanding, normally being used in every declaration of the king (CONGADA..., 2005).

Scene 7 - Second war - Fight between noblemen of Congo and the people of Angola - The Ambassador's arrest: the supporting actors of the Lapa's Congada, for the episodic orientation of the development of the play, name the first war as the initial pursuit of the Prince with the Ambassador and the skirmishes that follow. The evolution of the ballet dancers and the figurative chants of warlike maneuvers of the episode that follows the retreat of the Ambassador are called the second war. Indeed, this scene evokes war, for the Prince commands a progress 
Projética, Londrina, v. 11, n. 1, supl. Design de Moda, p. 104-137, maio 2020

of the noblemen towards the side of the Ambassador's troupes, they fight, there are commanding voices instigating the combatants, weapons cross in the air, swords and spears, the fight is violent, and it ends with the arrival of the King to the battlefield, accompanied by the Standard-bearer and the Little Prince. The King gets a pistol, offered by the Little Prince, and blows it against the Ambassador, who surprised, falls to the ground. Arrested by the noblemen, he surrender his men and, all kneeling, the little congos weep for peace. They take over the noblemen's arms and spears (FERNANDES, 1977, p. 12).

This is the most modified scene. Firstly, the music is lightly changed, the rhythm is close to the noblemen's dance in scene 3. The second change is that the King arrives at the battlefield with the Queen, the Little Prince, the Secretary and the Prince. In the 1951 Congada, the Standard-bearer and the Little Prince accompanied the King. In the fighting scenes, the King does not use a weapon to stop the Ambassador. The war ends with the arrival of the King, without much fighting (CONGADA..., 2005).

Scene 10 - The Surrender of the Embassy: in the embassy, we have the impression that the Queen Ginga of Angola is sent knowing through the King of Congo that the festival of Saint Benedict was being celebrated, determined that all the embassy would be sent, as evidence of her respect and love to the most sublime Saint. The embassy is constituted of her most noble men. It ends with her manifestation of kissing the royal hands, and the musicians and dancers sent can finally join the brilliant function. With this explanation, the King manifests his joy in knowing the reason for the Queen's embassy, which tributes his reign and, offering an alliance to the state crown, ends affirming that Saint Benedict will repay it greatly.

Continuing the mission that was given to him by Queen Ginga, the Ambassador asks permission from the King to call on the musicians he brought to sing and dance in honor of Saint Benedict. Given royal permission, the chants and dances by the little congos, chiefs and guides follow. (FERNANDES, 1977, p. 13). 


\section{Costumes on set: Congos's symbolic language}

LINKE, P. P.

There are not many changes in this scene. The Ambassador sits to the left of the King, gives away his embassy and explains the reason for all his joy. He explains that he came to celebrate the black Saint that his Queen Ginga would like to appreciate such party with an embassy. Afterwards, the Ambassador calls his musicians to dance and sing. The rhythm in this scene is a bit different. The basic steps do not change much. In this scene, each little congo speaks a verse of the song (CONGADA..., 2005).

When analyzing these scenes, it is possible to notice what is changed and what is maintained in the celebration. Furthermore, it is noticeable that those aspects go beyond the composition of the scene, reaching the revitalized costumes. On the three pictures, it is possible to see how rich in details the royal vests are, and how striking the garments and elegance are, revealing the importance of the characters and their symbolic meanings.

The royal vests are red and white, with golden details. They are exclusive of the royalty during the celebration. It marks the distinction from other characters. "In the secular life, white has always represented purity and innocence. [...] Because it gets dirty, physically and symbolically, with such joy, white has always been popular among those who wish to show wealth and status through the conspicuous usage of soap or the abundance of workforce" (LURIE, 1997, p. 198).

White represents purity, innocence, status and marriage. Since ancient times, artists paint angels with white vests, meaning purity, innocence and serenity (PEDROSA, 2003). "Red, before all, is the color of blood. Traditionally, it represents strength, vitality and heat" (LURIE, 1997, p. 208). In this case, red represents status, due to the difficulty of obtaining it and its high cost, as well as a reference to power, related to force and war. Golden appears representing gold and wealth (PEDROSA, 2003). It is present in the royal crown, jewels, the king's scepter, and hemstitched of the royal clothing. 
Projética, Londrina, v. 11, n. 1, supl. Design de Moda, p. 104-137, maio 2020

Another important factor to be observed is the use of velvet in the cloaks, as well as the presence of laces in the Queen's dress and in the veil of the King and the Little Prince's cloaks. Besides velvet, a fabric normally used by the royalty, and fine laces, there are other elements that can serve as distinction, in this case, the use of white gloves which indicates those who do not need to worry about physical labor.

The scepter, the crown and the cloak, as well as the royal throne, are signs that legitimate the King's power. They are instruments that emphasize the royal figure over the rest of the court, making his power stand out. The throne, in this celebration, has an important role. It represents the power of royalty. It allows the royal family to observe the party the noblemen make, as the King is in a higher position, watching "from above", sitting in his throne, enjoying the show.

Regarding the celebration as a whole, the level of distinction between the two courts stands out, as well as the space dedicated to each scene and the way the costumes differentiate each group.

It is worth pointing out the refinement of the royal family's and the Ambassador's vests. The combination of colors and their harmony make them different from the noblemen costumes, which use strong colors with a higher number of information. Maximalists in relation to the royal costumes, minimalists in relation to the embassies. When compared to each other, it is observed in costumes of the two cuts differences in colors and ornaments representing the difference in power and status between groups.

The minimalism, as the name says, is the purest and cleanest form, without excesses and exaggerations. It's the basic. Straight lines, followed by a reduced number of information, a clean and clear look. Maximalism, on the other hand, works with the overload of information, a more baroque style, in which exaggeration was preached, uniting various styles and information in a single look (CALDAS, 1999). 


\section{Costumes on set: Congos's symbolic language}

LINKE, P. P.

The costumes worn by the noblemen have a lot of information (strong colors and contrasts) which cause greater visual impact, while those of the Embassy (little congos, Chiefs and Guides) have less information, but the colors are strong and coordinated among them. The royalty and the Ambassador wear strong colors, but their accessories, garments and colors are combined in a way that creates a cleaner and more coherent visual identity, revealing power and elegance at every detail. Therefore, the clothing of these groups presents itself as a form of distinction and power, marking social standing.

The costumes of the employees show the hierarchy inside the court of Kongo and the Embassy and the relation between the two groups. The weapons used also help in this process. In the embassy, only the Ambassador, the Guide and the Chief have swords. The rest of the troup use spears, rustic weaponry. Whereas in the Court of Kongo, all the noblemen and the King use swords, more refined weaponry that also help in the celebration as instruments that are a part of the protocol acts, beautifying certain elements of the choreography.

The sword "made essentially of blade and guard [...] is simultaneously a symbol of the wound and of the ability to wound. That is why it is a symbol of freedom and strength" (CIRLOT, 1984, p. 236). It highlights the military power of Kongo upon the other embassy visitors, which also uses swords as weapons, but in lower numbers. The swords is also a symbol "reserved to the knight, defender of the light against darkness" (CIRLOT, 1984, p. 237).

The kingdom of Congo is a Christian one, representing the light. The visiting embassy, still pagan, represented by Angola, would be the darkness that insults the King of Kongo, which is overwhelmed by the power of the other army. The sword as a weapon is efficient. It shows military power and the strength of a kingdom under the protection of the Saint. The weapon is also recognized as a symbol of "spiritual evolution" (CIRLOT, 1984, p. 237). This way, it helps to demonstrate the Kongo King's power, military superiority and the strength of light and spiritual superiority. 
Projética, Londrina, v. 11, n. 1, supl. Design de Moda, p. 104-137, maio 2020

However, the spears used by the little congos are "war weapons [...]. Weapons of the earth, as opposed to the divine character of the sword" (CIRLOT, 1984, p. 334). Because of this, it is understandable that the Prince's mistake was to think that the visiting embassy was an enemy, since it had a great amount of well-armed soldiers. The spear, as a symbol of war, is inferior to the power of the sword, consequently the power of Kongo, which does not manifest only through the weapons, but also in the dressing, full with details, showing that the kingdom is financially prosperous, because it has treasures to spend with costumes and festivals to honor the Saint.

This way, the differences between the court and the characters that are part of it demonstrate the positions that both the kingdoms occupy. Just like the sovereigns, the King of Congo and the Queen of Angola, which represent the past of a mythical and powerful Africa, remained in the memory of the African-descendant people. The image of these two sovereigns is connected to power and wealth, as well as to freedom, wars, resistance and transformations, which the Africans went through and brought along into the New World.

\section{FINAL CONSIDERATIONS}

The material culture of the Congada is full of elements that represent the power and faith in a black Saint. With the process of revitalization, the material culture of the play has undergone some modifications. It did not lose its basic elements, because the reconstitution of the objects, costumes and instruments was based on photos and in the statements of members of the group. Thereby, there was a preoccupation in keeping the highest degree of similarity with the costumes and objects used in old times. However, there is also the presence of personal taste, since the participants interfere with the choices and add their personal values to the costumes, which appear in an intrinsic way and which makes the costumes more modern, even though they represent another reality. 


\section{Costumes on set: Congos's symbolic language}

LINKE, P. P.

Observing the characteristics of the Congada's costumes, the Portuguese influence is perceptible. The presence of African elements is also undeniable in the verses and in the music. The tradition is maintained in the songs, choreography, costumes and verses that compose the celebration. Barthes (2005) refers to the importance of the costume in a play, highlighting that the outfit stimulates the sight through colors, forms and textures. This allows the characters to create and recreate alternative realities, which gain life and shape assisted by sound resources. Thus, the costumes used in the Congada express the re-appropriation of many cultural elements. It is also a way that individuals found to preserve their memories. In the case of preservation of traditions, each individual adds values to the clothing, values that are not only connected to culture, but to the individual's identity, the kind of life he or she leads and the world he or she lives in.

The Congada is seen as a multiple cultural element, with influences that go beyond its origin in Lapa. It remembers a harsh African past, and lives diverse transformations with changes and permanence that tell its journey, its fights, defeats and accomplishments.

The cultural multiplicity was caused by the blending of African, Portuguese and Brazilian elements and manifests itself through music, dance, scenery and dressing. The combination of diverse, distinct cultural elements gives the festival unique features.

When it comes to dressing, the changes caused by the process of transformation and the role of the revitalization process must be pointed out. Still, the worry of keeping alive the main symbols of the celebration must be emphasized. In this specific case, dressing suffers the influence of the individual who adds new elements and substitutes others. The changes that occur in the typical costumes of the festival are expressions of those who act their roots, beliefs and traditions. 
Projética, Londrina, v. 11, n. 1, supl. Design de Moda, p. 104-137, maio 2020

In this celebration, costumes have a leading part, as they help in the building of characters and of the kingdoms of Kongo and Angola. The differences and similarities express features that differentiate both groups and reveal the existing hierarchy between the characters. The vests reinforce levels of power and authority. The study of dressing is important because it helps in the process of understanding the celebration and its symbol. All the elements that make up the celebration are inserted in the dynamic of culture and, as it is with culture in general, the Congada is subjected to changes caused by time and by the individuals who organize and stage it. The concern exposed here is that of keeping alive the memories that are a part of our history. The congos's group is divided in two kingdoms, with the court of the Congo and the Embassy of Angola being presented in distinct forms: each specific group with specific clothes and weaponry, disclosing the cultural differences which exist between them.

This text aims to explicit how clothing functions as a symbolic and meaningful component of the Lapa's Congada. In order to discuss the meanings of clothes, the cultural elements that surround the individual must be considered. Analyzing how clothing is used in plays without considering the context is to disregard the elements, which build the language of clothing. Therefore, it is necessary to know the different cultures that are part of the play, their origins and how the subjects appropriate elements to build a visual language and to express their tradition through a symbolically rich material culture, which encompasses the clothing of the participants along with dance or music.

The role of clothing as a symbolic and meaning component of Congada is explicated, thus, as they aid in the distinction between characters along with weapons and accessories, demonstrating the degree of importance of each one in the celebration. In this case, the costumes assist in the building process of the celebration as they characterize and distinguish the characters, locating them within time and space. The clothes assist in the building of a language that expresses the identity of the group, its conflicts and preferences. 


\section{REFERENCES}

1. ALMEIDA, Paulo Roberto de; KOURY, Yara Aun. História oral e memórias. Entrevistado: Alessandro Portelli. História e Perspectivas, Uberlândia, v. 50, p. 197-226, jan./jun. 2014.

2. ARIZPE, Lourdes. El patrimonio cultural inmaterial de México: ritos y festividades. Ciudad de México: Miguel Ángel Porrúa, 2009.

3. BALDINI, Mássimo. A invenção da moda: as teorias, os estilistas, a história. Lisboa: Edições 70, 2005.

4. BARNARD, Malcolm. Moda e comunicação. Rio de Janeiro: Rocco, 2003.

5. BARTHES, Roland. Imagem e Moda. Tradução de Ivone Benedetti. São Paulo: Martins Fontes, 2005.

6. BOSI, Ecléa. Memória e sociedade: lembranças de velhos. 3. ed. São Paulo: Companhia das Letras, 1994.

7. CALDAS, Dario. Universo da moda: curso on line. São Paulo: Anhembi Morumbi, 1999.

8. CASCUDO, Luís da Câmara. Dicionário do folclore brasileiro. 5. ed. Belo Horizonte: Editora Itatiaia, 1984.

9. CEZAR, Lilian Sagio. A utilização de conjuntos de imagens fotográficas no jornalismo enquanto uma das formas de representação da Congada nos media. Disponível em: http://www.studium.iar.unicamp.br/17/04.html?studium=index.html. Acesso em: 15 dez. 2008.

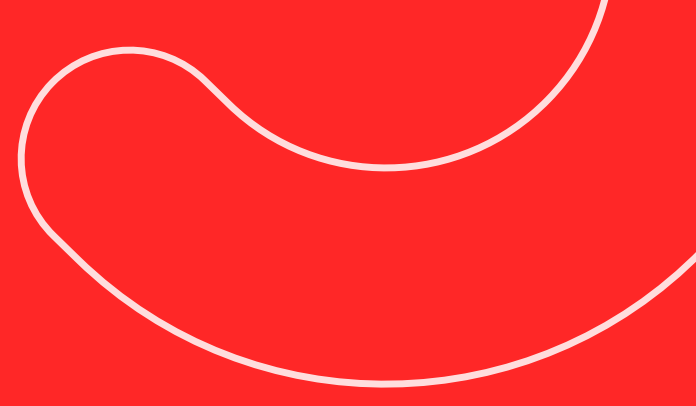


Projética, Londrina, v. 11, n. 1, supl. Design de Moda, p. 104-137, maio 2020

10. CHARTIER, Roger. A história cultural: entre práticas e representações. Lisboa: Difel, 1988.

11. CIDREIRA, Renata Pitombo. Os sentidos da moda: vestuário, comunicação e cultura. São Paulo: Anablume, 2005.

12. CIRLOT, Juan-Eduardo. Dicionário de símbolos. São Paulo: Moraes, 1984.

13. CONGADA da Lapa. Produção: Lux Agência de Desenvolvimento. Lapa: Videolar, 2005. 1 DVD (117 $\mathrm{min})$.

14. COSTA, Francisco Araújo. O figurino como elemento essencial da narrativa. Sessões do Imaginário, Porto Alegre, v. 4, n. 8, p. 38-41, ago. 2002. Disponível em: http://www.pucrs.br/uni/poa/famecos/imagina/edicao-8/araujosed8. pdf. Acesso em: 7 mar. 2012.

15. CRANE, Diana. A moda e seu papel social: classe, gênero e identidade das roupas. São Paulo: Senac, 2006.

16. FERNANDES, José Loureiro. Congadas paranaenses. Rio de Janeiro: MEC: Fundação Nacional de Arte - FUNARTE, 1977.

17. FONSECA, Maria Cecília Londres. O patrimônio em processo: trajetórias da política federal de preservação no Brasil. 3. ed. Rio de Janeiro: Editora UFRJ, 2009. 


\section{Costumes on set: Congos's symbolic language}

LINKE, P. P.

18. FONSECA, Maria Cecília Londres. Para além da pedra e cal: por uma concepção ampla de patrimônio cultural. In: ABREU, Regina; CHAGAS, Mário (org.). Memória e patrimônio: ensaios contemporâneos. Rio de Janeiro: DP\&A, 2003.

19. GEERTZ, Clifford. A interpretação das culturas. Rio de Janeiro: Zahar, 1998.

20. HEYWOOD, Linda M. Diáspora negra no Brasil. São Paulo: Contexto, 2010.

21. LE GOFF, Jacques. Documento/Monumento. In: História e memória. Tradução de Suzana Ferreira Borges. 3. ed. Campinas: Unicamp, 1994.

22. LINKE, Paula Piva. A congada da Lapa - PR: um patrimônio cultural: a indumentária como um signo identitário. 2012. 172 f. Dissertação (Mestrado em História) - Universidade Estadual de Maringá, Maringá, 2013.

23. LURIE, Alison. A linguagem das roupas. Rio de Janeiro: Rocco, 1997.

24. MAUAD, Ana Maria. Através da imagem: fotografia e história. Interfaces. Tempo, Rio de Janeiro, RJ, v. 1, n. 2, p. 73-98, 1996.

25. NASCIMENTO, Cláudia Bibas do. Múltiplos olhares sobre a presença negra na Lapa - Paraná: história e arqueologia (séculos xix e xx). 2009. Dissertação (Mestrado em História das Sociedades Ibero-americanas) - Universidade Católica do Rio Grande do Sul, Porto Alegre, 2009. Disponível em: http://tede. pucrs.br/tde_busca/arquivo.php?codArquivo=1988. Acesso em: 7 mar. 2012. 
Projética, Londrina, v. 11, n. 1, supl. Design de Moda, p. 104-137, maio 2020

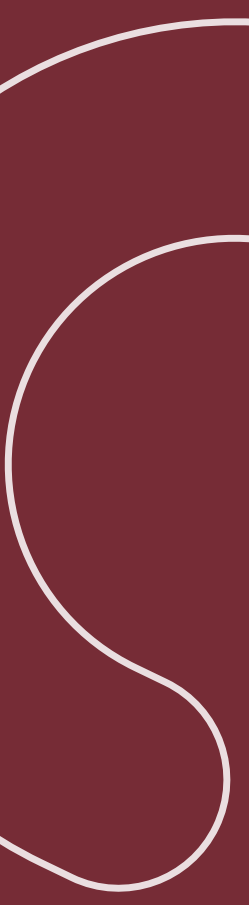

26. NERY, Marie Louise. A evolução da indumentária: subsídios para a criação de figurino. Rio de Janeiro: Senac Nacional, 2003.

27. ORLANDI, Eni Puccinelli. Análise de discurso: princípios \& procedimentos. Campinas: Pontes, 2003.

28. ORLANDI, Eni Puccinelli. Discurso e texto: formulação e circulação dos sentidos. Campinas: Pontes, 2001.

29. PEDROSA, Israel. Da cor à cor inexistente. Rio de Janeiro: Léo Christiano, 2003.

30. REIS, João José. A morte é uma festa: ritos fúnebres e revolta popular no Brasil do século XIX. 3. ed. São Paulo: Companhia das Letras, 1991.

31. REIS, João José. Tambores e temores: a festa negra na Bahia na primeira metade do século XIX. In: CUNHA, Maria Clementina Pereira. Carnavais e outras festas: ensaios da história social da cultura. Campinas: Editora da Unicamp, 2002.

32. SILVA, Ana Lúcia da. A tradição popular: a religiosidade e a expressão da cultura afro-brasileira em uma das cidades históricas paranaenses; a Congada na Lapa. 2007. Disponível em: http://www.dhi.uem.br/gtreligiao/pdf/st1/ Silva,\%20Ana\%20Lucia \%20da.pdf. Acesso em: 9 abr. 2009. 
33. SILVA, Wagner Aparecido da. Viva rei, viva rainha, viva também seu capitão: a família do congado em Conselheiro Lafaiete MG. 2008. Dissertação (Mestrado em Educação, Arte e História da Cultura) - Universidade Presbiteriana Mackenzie, 2008. Disponível em: http://mx.mackenzie.com.br/tede/tde_busca/arquivo.php?codArquivo=900. Acesso em: 9 abr. 2009.

34. SOUZA, Marina de Mello. Reis negros no Brasil escravista: história da festa de coroação de rei congo. Belo Horizonte: Editora UFMG, 2006.

35. WAJNMAN, Solange; ALMEIDA, Adilson José de. Moda, comunicação e cultura: um olhar acadêmico. São Paulo: Arte \& Ciência, 2002.

36. ZANIRATO, Sílvia Helena. A documentação fotojornalística na pesquisa histórica. Trajetos: Revista de História UFC, Fortaleza, v. 2, n. 4, p. 205-218, 2003. Disponível em: http://www.repositorio.ufc.br/handle/riufc/19974. Acesso em: 9 abr. 2009.

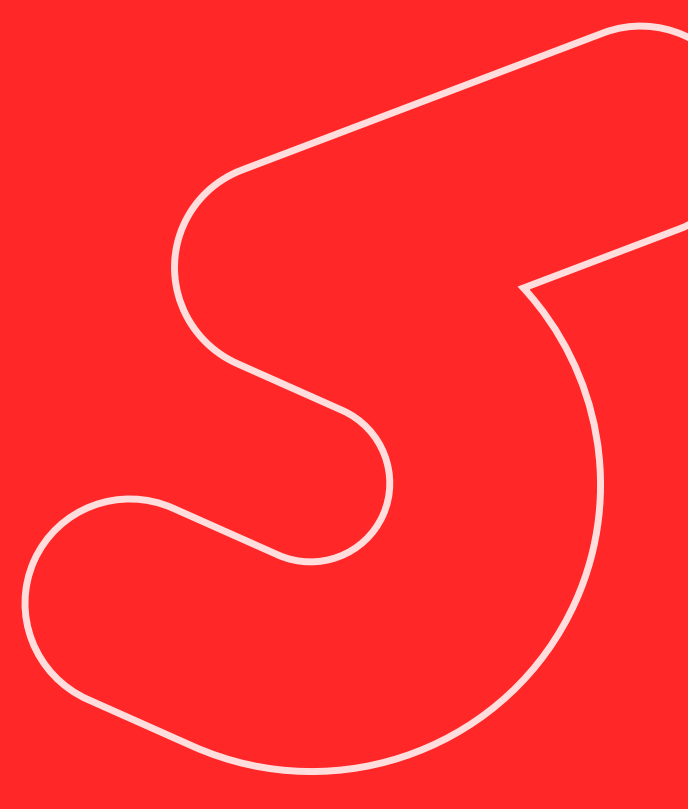

